\title{
Hasan Hanafi, new theology and cultural revolution: An analysis of cultural intensification
}

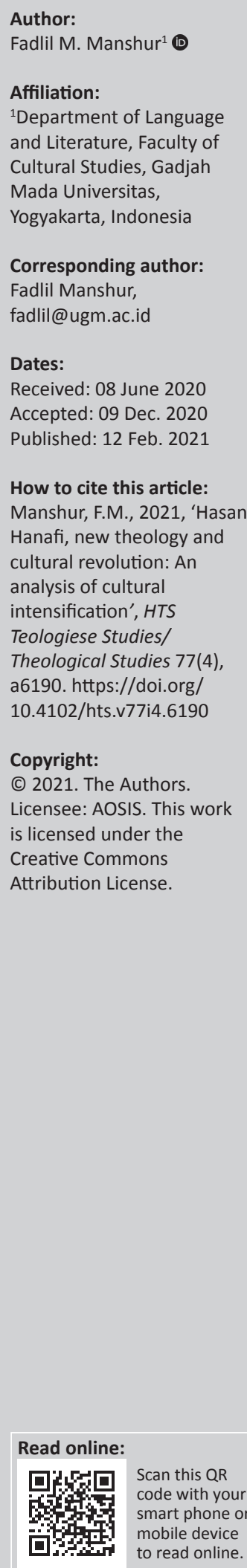

\begin{abstract}
In the perspective of Hasan Hanafi, the renewal of Islamic thought in the Arab world must produce a new concept of theology and present a cultural revolution. A new theology must be developed through a progressive life perspective rooted in liberation and social justice. It is intended to free Arab-Islamic society from regression and fragmentation, producing a society that is just, prosperous and civilised. The renewal of Islamic thought must be progressive to ensure that it can produce a cultural revolution that can create a populistic social and ideological structure in Arab life, thereby ensuring that the faithful are intelligent, modern and have a high level of social solidarity. This study is guided by the theory of cultural intensification, which emphasises that the relations between individuals and society are rooted in sociological, psychological and theological challenges and holds that social and divine laws are intended to promote a human emotional involvement in social life. The analysis emphasises the relationship between Hasan Hanafi, as an individual, with general Arab society, with a focus on his understanding of social challenges, the psychological condition of Arab society and classical theology. This study indicates that the Arab-Islamic world requires a new theology, one that is anthropocentric, populistic and transformative, which remains grounded and oriented towards the realisation of prosperity and social justice. Cultural revolution, meanwhile, offers a liberational ideology for the subjugated and legitimisation for every social struggle. It also holds that no entity that exists on its own, without any humanitarian context, has meaning; there is only a correlational truth connecting objective reality and universal human values. As such, new theology - in conjunction with cultural revolution - can radically transform the orientation of Arab-Islamic thought from static, passive and traditional to progressive and oppositional. In doing so, it can offer liberation and social justice.
\end{abstract}

Contribution: This article provides an intellectual framework to dissect Hasan Hanafi's new theological ideas by using cultural perspective, particularly cultural intensification theory, as well as work praxis in an effort to build democratic, egalitarian, just, equality before the law and uphold human rights of Muslim society.

Keywords: new theology; cultural revolution;liberation; social justice; populism; contemporary reality.

\section{Introduction}

Hasan Hanafi is one of a number of modern Arab thinkers whose progressive ideas have broken through the limits of traditional Arab thought. The formalistic and traditional tendencies of mature Arabic cultural thought have led him to offer a more radical approach, particularly to academics. Amongst his contemporaries in modern Arab-Islamic thought are Mohammed Arkoun, Abed al-Jābiry, Nashr Hamid Abu Zayd and Husayn Marwah (Browers 2004:367-379). These Arab-Islamic thinkers share Hasan Hanafi's vision and his desire for a cultural revolution in Islamic thought that enables Arab Muslims to shed the chains of religious dogmas that stifle human creativity. In his discussion of the stagnation of Islamic thought, Hasan Hanafi has been influenced by Tylor's concept of religious intellectuality, Freud's psychoanalysis and Durkheim's sociological analysis - all of which have radical, and at times even conflicting, paradigms. Given such complexity, it is not surprising that many scholars, such as Daniel L. Pals, have argued that nobody can comprehensively and inclusively interpret religion (Phillips 2003:2).

Hasan Hanafi and his contemporaries, whilst being influenced by modern Western philosophy, desire a cultural revolution in the Arab-Islamic world that can promote progress and curb the degradation of religiosity in the Arab world. This degradation, they argue, has occurred because many modern Arabs see religion as an individual matter, and as such institutionalised religious 
teachings no longer draw their attention. Some Arab societies place great importance on individual piety, rites of worship, spiritualism and personal morality and are less concerned with public affairs. In other words, the modern world has enabled spirituality to become a highly individual matter, and this situation must be considered when formulating a useful model of religion. For example, one may understand religion from the perspective of folk language and from individual cultural expression, which both enable an understanding of the dynamic interactions amongst belief, practice, narrative, perceptions and personal experiences (Sutcliffe \& Bowman 2000). It is in this context that Hasan Hanafi has interacted with Arab society in matters of faith, religious practice, mental attitudes and cultural reasonings to produce critical narratives of religion and perceive his personal experiences as an ArabMuslim scholar (Hanafi 1989a:12).

In his social and intellectual interactions with contemporary Arab-Muslim thinkers, Hasan Hanafi has offered a progressive model of Islamic thought, showing that ArabMuslim society must be driven to close the gap between itself and Western society, which has achieved significant scientific and technological progress whilst advancing the fields of information and communication. Building on this brief background, this study explores the progressive contemporary thought of Hasan Hanafi, who has used a post-fundamentalist and post-structuralist approach to advance the concepts of new theology and cultural revolution. These two concepts have been used by Hasan Hanafi as instruments for promoting a just, prosperous, democratic and civilised Islamic society. The postfundamentalism approach, or as Olivier Roy (1996) called Post-Islamism, is an approach of an Islamic movement that is increasingly adapting itself to the space of democracy and human rights, so that it is no longer an Islamic movement that rejects the jargon of modernism. The post-structuralism approach contains both criticism and absorption, that is criticism of the structure of modern society, and at the same time absorbs some of these values (Poster 2019:28). Both approaches are used to explain Hanafi's thoughts, which aspire to create a democratic Muslim society.

Islamic civilisation is conceived as a wheel rotating around a core divine message, one passed from Allah to the prophets (from Adam to Muhammad). Islamic civilisation is a blend of Islamic normativity and historicity. Islamic normativity is the holy book texts that are the reference and source of Islamic teachings, whilst Islamic historicity is Islam as understood and manifested in the history of Muslims (Abdullah 2006:36). Because of this divine source, it has been seen as offering a transcendental truth and reason. Furthermore, although Islamic civilisation has gone in many directions, it has remained near its source, moving fastest at its margins. The source of Islamic civilisation is the divine message of Allah, which is practised in everyday life and history (Said, Abu-Nimer \& Sharify-Funk 2006:89). However, Arab-Islam civilisation tends to lean towards Western civilisation, which has experienced the achievement of very advanced science and technology; therefore, this trend can have implications for the marginalisation of Arab-Islam identity values. Hasan Hanafi argues that the inherited structure of Islamic theology reflects the general power structure in Muslim societies and supports the strong against the weak, the elite against the masses (Hanafi 1987a:34). For Hanafi, theology is a reflection of revelation that utilises the vocabulary of his time and is driven by the needs and goals of society (Hanafi 1989c:4). Theology is the projection of the needs and goals of human society into scriptural texts. Theology is a belief that represents thoughts, attitudes, ideals and actions of mankind; therefore, it is not only in the realm of abstract belief, but it is part of social structure that encourage and inspire the society. Every theologian or interpreter sees the holy book as something they want to see (Hanafi 1982:59). This shows how man depended for his needs and goals on these texts. Therefore, theology can act as an ideology of liberation for the oppressed or as a justification for colonialism by the oppressors. As such, Hasan Hanafi has desired a renewal in Islamic thought, a progressive approach that is oriented towards producing a new theology and cultural revolution in the Arab world.

There are two problems being discussed in this article. Firstly, why is a new theology needed in the Arab-Islamic world to produce an integral solution to the problems facing the ArabIslamic world, including the stagnancy of classical theology? Secondly, why is a cultural revolution needed in the ArabIslamic world, a revolution that criticises the stagnancy of Arab thought and its regression and fragmentation? The study of these two issues is seen as important in providing an intellectual framework and practical work in the effort to build a Muslim society that is democratic, egalitarian, just, equal before the law and upholds human rights. Many studies on Hasan Hanafi have been carried out from various perspectives ranging from theological perspectives, philosophy, hermeneutics, fiqh, Islamic politics and others. In this article, the study of Hanafi uses a cultural perspective, which is still very rarely done so far.

This study is guided by the theory of cultural intensification, which understands the relationship between individuals and society as being rooted in sociological, psychological and theological challenges (Davies 2016:1-2). According to this theory, social and divine laws are intended to promote a personal/collective emotional involvement in social life. The social sciences view 'meaning-making' as closely linked to a specific philosophical background, namely phenomenology; as such, this concept of 'meaning' may be linked to the concept of 'salvation' in religious tradition. Psychology, meanwhile, is more experimental in its search for meaning and understanding of human cognitive processes. However, it often forgets to understand individual meaning-making processes as both influenced by society and by individual personality (Beyers 2017:4). As such, a biographical narrative offers a valuable means of balancing the plasticity of the 'social group' and the construction of personal life (Day 2016:8).

In this article, the theory of cultural intensification is used to emphasise the relationship between Hasan Hanafi as an 
individual and Arab society in understanding the social challenges and psychological condition of the Arab people, as well as their classical theology. Hasan Hanafi argues that a gap exists between the social fact of Arab society and the divine law, as well as perfect and ideal that has been given to them. As such, Hasan Hanafi has tried to combine social life and personal/collective emotional involvement to obtain effective solutions and produce new understandings of Islamic thought as part of the human cognitive process, with the ultimate goal of promoting a new theology and cultural revolution.

\section{Results and discussion}

\section{Hasan Hanafi's concept of new theology for liberation and social justice}

Before discussing the concept of new theology, or that of cultural revolution, it is necessary to first present a biography of Hasan Hanafi and the points that influenced his conceptualisation of new theology, liberation and social justice.

Hasan Hanafi was born on 13 February 1935, in Cairo, into an academic tradition that drew influence from the great civilisations of the Pharaohs, the Romans, the Byzantines, the Arabs, the Turks and even the modern Europeans. This underscores the importance of Egypt, particularly Cairo, in the early development of Hasan Hanafi's academic understandings. By examining Hanafi's ideas and intellectualism, it is obvious that the development of Hanafi's thought and intellectuality had a strong influence on the socio-political conditions of Egypt, especially the ideas and movements of nationalism and the Egyptian revolution.

In his youth, Hasan Hanafi faced the reality of colonialism and foreign oppression. This imbued him with a sense of patriotism and nationalism, and as such it is not surprising that, by age 13, he asked to join Egypt's 1948 war against Israel. However, because of his young age, he was rejected by the Muslim Youth. Although Hasan Hanafi was disappointed, this experience made him aware that the Egyptian people were facing problems of unity and fragmentation. In the future, his awareness of the problem of the unity and division of the Egyptian nation coupled with the influence of Egyptian nationalism and revolution has stimulated his enthusiasm to develop a new theology that is able to free the Egyptians from various socio-political tyrants, whilst at the same time realising an Egyptian nation that upholds democracy and human rights.

In 1951, whilst still attending senior high school, Hasan Hanafi saw for himself how the English soldiers were killing Arab martyrs at the Suez Canal. He thus joined a student movement, and ultimately was part of Egypt's 1952 resolution. Upon the recommendation of the Muslim Youth, he decided to join the Muslim Brotherhood. However, in this organisation he found debates similar to those of the Muslim Youth, and Hasan Hanafi was urged to join the Young Egyptians. There, too, he found the same problems, and Hasan Hanafi grew dissatisfied with the fragmentation of the Muslim youths in Egypt. As a result, he decided to focus on obtaining a better understanding of Islamic thought, revolution and social change. He became interested in the thought of Sayyid Qutb, particularly his arguments regarding social justice and Islam (Hanafi 2016:14-15). However, unlike Sayyid Qutb - who was interested in politics and moved in secret, Hanafi purely placed himself in the position of intellectual criticism of all existing power structures. Hanafi spoke and worked openly, or, according to John L. Esposito and John Voll, working 'above ground' (Esposito \& Voll 2001:66). Hanafi was not involved in the secret revolutionary movement.

As such, from youth Hasan Hanafi was steeped in the revolutionary atmosphere of contemporary Egypt, particularly the Egyptian people's struggle to end English colonial rule, as a result of which the English people had become divided, Islamic thought had stagnated and social change had slowed.

Between 1952 and 1956, Hasan Hanafi studied philosophy at the University of Cairo. During this period, he experienced Egypt's darkest days. For example, in 1954 a major clash broke out between the Muslim Brotherhood and the revolutionary movement. Hasan Hanafi sided with President Mohamed Naguib in opposition to Prime Minister Gamal Abdul Nasser, arguing that the former had a clear commitment to Islam as well as an Islamic vision. His various experiences during this period of conflict, particularly on campus, drove him to become a reformist. He asked himself why Muslims were always defeated during conflict, and why internal struggles seemed unending (Hanafi 2016:15). This question, he felt, could only be answered by offering a new theology to the Arabs of Egypt, arguing that the stagnancy they were experiencing was caused in part by a static and classical understanding of theology.

Subsequently, Hasan Hanafi had the opportunity to study at Sorbonne University, France (1956-1966). There he found an environment conducive to understanding the fundamental problems being faced by his countrymen as well as possible solutions. It is in France that helearned to take a methodological approach, both through his lessons and through the orientalist works he read. Under the Catholic modernist Jean Guitton, for example, he learned about the methodology of thought, renewal and the history of philosophy. Hanafi even mentions Jean Guitton as his master (teacher) who is responsible for all of his philosophical formations (Esposito \& Voll 2001:75). He studied phenomenology under Paul Ricoeur, learned analysis of consciousness under Edmund Husserl and was guided in writing about the renewal of Islamic jurisprudence by Louis Massignon (Hanafi 2016:15). This methodological training prepared Hasan Hanafi for formulating and promoting a new, dynamic understanding of theology (Hanafi 2012:7-16). The idea of building a new dynamic theology was influenced, amongst other things, by Islamic Socialism that later became popular with 'the Islamic Left'. Hanafi argues that Islamic traditions built on old theological foundations are inherently more attractive to elites than to the majority of the Muslim 
community. On the contrary, the Islamic Left emphasises the differences within an Islamic community between the rich and the poor, the strong and the weak and the oppressors and the oppressed. The Islamic left represents the silent majority of the oppressed, supporting the weak against the strong, considering everyone equal because, according to Hanafi, there is no difference between Arabs and Persians except in piety and doing good deeds (Esposito \& Voll 2001:69).

From this overview, it can be clearly seen that Hasan Hanafi was heavily influenced by modern Western philosophers and philosophy, including phenomenology. For example, he was influenced by Martin Heidegger through his book Being and Time (1962; first published in German as Sein und Zeit in 1927). This book was central in the development of existentialism in the 20th century, as well as the school's interpretation of phenomenology. Many influential 20thcentury philosophers were influenced by phenomenology, including Hannah Arendt, Hans-Georg Gadamer, Emmanuel Levinas and Herbert Marcuse. In France, Jean Paul Sartre read the works of Husserl and Heidegger before developing his own version of existentialism. Another important French philosopher, Maurice Merleau-Ponty, is widely considered a phenomenologist in the Husserlian tradition and described by Dermot Moran in Introduction to Phenomenology as having produced France's most original work of post-Husserlian phenomenology (Cox 2006:9). Of the many Western philosophers, there are three thinkers who guide Hanafi's intellectuality. All of the three are philosopher Paul Ricoeur, Catholic theologian Jean Guitton and Islamist Robert Brunschvig (Kersten 2019:33). The three of them played an important role when Hanafi published Hanafi's first three monumental works (Allosh 2018:78-79). Hanafi's three early works are Methods of Exegesis: Essays on the Science of the Fundamentals of Understanding in the Discipline of Usūl al-Figh (1964), The Exegesis of Phenomenology, the State of the Art of the Phenomenological Method and Its Application to the Phenomenon of Religion (1965) and The Phenomenology of Exegesis: An Essay in the Existential Hermeneutics of the New Testament (1965).

Hasan Hanafi's desire to promote a new theology in the Arab world became even stronger after he returned from France in 1966. However, Israel's defeat of Egypt in the 6-Day War of 1967 changed his direction as he sought to restore Egyptians' sense of nationalism. For this, he applied the academic knowledge he had obtained and integrated the mass media into his struggle. Hasan Hanafi wrote numerous articles responding to contemporary issues and highlighted several shortcomings in Islamic society (Hanafi 1983b:7), particularly Muslims' lack of an intellectual culture and limited progress in the fields of science and technology.

During this time, Hasan Hanafi also taught at the University of Cairo as well as several foreign universities. He was a guest lecturer in France (1969) and Belgium (1970), and then spent 4 years teaching at Temple University, United States. The Egyptian government, distressed by his activities, had given Hasan Hanafi two choices: to continue his activities or to travel to the United States. Whilst in the United States, he had the opportunity to write extensively about interfaith dialogue and revolution. Only after his return to Egypt did he begin writing further about the renewal of Islamic thought, working on the book Al-Turāth wa al-Tajdìd. However, this book was left unfinished as he returned to writing in the popular media as movements against the Anwar Sadat government and its perceived pro-Western and pro-Israeli policies emerged; the works published in this period were later compiled in the book Al-Din wa al-Tsaurah. During the 1980s, Hasan Hanafi continued to teach; he served as a guest lecturer at the University of Tokyo (1980-1983) and in the United Arab Emirates (1985). Whilst teaching in Morocco between 1983 and 1984, he contributed to the establishment of Fez University (Hanafi 2016:15).

The book Al-Din wa al-Tsaurah deals primarily with the relationship between religion and revolution. In it, Hasan Hanafi argues that religion and theology guided humanity in understanding the Divine. However, he views the Arab understanding of theology as lacking, as Arab Muslims have long understood religion as static, a fact that has hindered progress. Hasan Hanafi thus argues for a new theology, one that can guide Muslims in dynamically and progressively understanding the teachings of their religion (Hanafi 1977a:21, 1977b:42). Furthermore, the book argues that revolution is necessary to transform Arab society and promote scientific and technological advancement.

During his intellectual journey towards this goal, Hasan Hanafi travelled extensively between 1980 and 1987, reaching countries such as the Netherlands, Switzerland, Portugal, Spain, France, Japan, India, Indonesia, Sudan and Saudi Arabia. His meetings with the major thinkers of these countries broadened his horizons and enabled him to gain a broader understanding not only of the problems facing the Arab Peninsula but also the broader Muslim world. His life experiences, from his teenage years through adulthood, gave him a significant concern for the problems of his fellow Muslims. As such, although he had not dedicated himself totally to a specific movement, he remained active. Similarly, his academic and intellectual experiences - both formal and informal - as well as his interactions with the major minds of the world honed his analysis and thought, thereby further driving his desire to create the new and dynamic theology that the Arab-Islamic world needed to end its stagnancy.

Hasan Hanafi's works may be divided into three periods, as done by several writers who have previously examined his thought: works produced in the 1960s, works produced in the 1970s (Hanafi 1977a:43, 1977b:23, 1977c:7) and works produced between the 1980s and 1990s (Hanafi 1989a:14, 1989b:36). In the early 1960s, Hasan Hanafi's thought was influenced most heavily by the dominant understandings in Egypt at the time, namely nationalism, populistic socialism and Pan Arabism, as well as the turmoil experienced by Egypt after its military defeat in 1967. Also, as previously mentioned, during this period (1956-1966) Hasan Hanafi spent time studying in France, where he gained a better 
understanding of philosophy and the social sciences. This further convinced Hasan Hanafi of the need for rejuvenating Islamic thought and creating a new, dynamic theology.

To produce his new concept of theology, whilst studying in France, Hasan Hanafi focussed on new methods of interpreting Islamic legal theory and using phenomenology as a means of understanding religion in contemporary society. This research laid the basis for his doctoral dissertation at Sorbonne University, titled Essai sur la Methode d'Exegese (Essays on Exegesis Methods), which argued for the use of Husserlian phenomenology in exegesis. In 1961, this 900-page dissertation was named the best Egyptian academic work.

In this early period, Hasan Hanafi's works were purely academic. Only at the end of the decade did he begin arguing that Islam needed to develop a progressive and liberational (taharrur) theology that can promote social justice and freedom. For manifesting such a dynamic understanding of Islam, he argued, a populistic social structure was necessary.

Hasan Hanafi believed that Israel's defeat of the Arabs in 1967 was caused, in part, by the lack of liberty and social justice in the Arab World. As such, his writings from the period underscore the importance of populism. This includes those works published in mass media publications such as Al-Kātib, Al-Adab, Al-Fikr Al-Mu'āshir and Mimbar Al-Islām. In 1976, these writings were compiled in the book Qadhāyā Mu'āshirat fi Fikrina al-Mu'āshir, which describes the reality of the contemporary Arab world, underscores Muslim scholars' duty to address the problems of the people and argues for an Islamic renewal that can promote a new theology. The following year, in 1977, Hasan Hanafi published Qadhāyā Mu'āshirāt fil-Fikri al-Gharīb, which outlines his conceptualisation of how the Arab people understand the problems facing their society and urges a renewal of Islamic thought. In this book, he references such Western scholars as Spinoza, Voltaire, Immanuel Kant, Hegel, Unamuno, Karl Jaspers, Karl Marx, Marx Weber, Edmund Husserl and Herbert Marcuse (Hanafi 1987b).

These two books, Qadhāyā Mu'āshirat fi Fikrina al-Mu'āshir and Qadhāyā Mu āshirāt fil-Fikr al-Gharīb, explore the two central tenets of his analytical approach and his understanding of Muslims' military defeats: positioning Muslims as inferior and the West as superior. To address the first issue, he emphasises the need to empower Muslims, particularly by transforming their mindsets. Secondly, he attempts to show how Western superiority is emphasised in every part of life. These tenets are at the foundation of two of his later works, namely Al-Turāth wa al-Tajdìd (Tradition and Renewal) and Al-Istighrāb (Occidentalism).

In the first years of the 1970s, Hasan Hanafi attempted to analyse the causes of the tensions between various elements of Egyptian society, particularly those between radical Muslim groups and the government. At this time, the political situation in Egypt was becoming increasingly tense, particularly as President Anwar Sadat exhibited pro-Western biases and was willing to compromise with Israel; this ultimately led to Sadat's assassination in October 1981. At this time, Hasan Hanafi began to believe that academics have a political responsibility to their nation. In this context, he wrote Al-Din wa al-Tsaurah fi Mishr, 1952-1981, an eight-volume collection of articles he had written between 1976 and 1981. These volumes explore national culture and its link with religion, the relationship between religion and nationalism, contemporary religious movements, fundamentalist Islam, 'leftist Islam' and national integrity. Citing various political tragedies, Hasan Hanafi argues that one major cause of the lengthy internal conflict in Egypt is the friction between Islamic ideology, Western ideology and socialism. He also examines the rise of Arab-Muslim radicalism.

Other works produced by Hasan Hanafi during this period is Religious Dialogue and Revolution and Dirāsat al-Islāmiyyah. The first, published in 1977, is a collection of works written whilst Hasan Hanafi was in the United States between 1972 and 1976. In the first part of this book, Hasan Hanafi recommends hermeneutics as a means of promoting dialogue between Muslims, Christians and Jews. The second section, meanwhile, deals with the link between religion and revolution and urges the use of phenomenology in interpreting Muslims' contemporary reality (Hanafi 2016:15). In his interpretation of reality, Hasan Hanafi appears to have been influenced by Dilthey, who identified a dualism between 'natural reality' and 'historical reality'. He also argued for the incomparability of mental order and natural order (Mantzavinos 2005:4), seeing human beings as often having difficulty facing the challenges of the times. In this context, Hasan Hanafi sees the Arab-Muslim people as impeded in their understanding of the idealistic natural world and the empiric historical reality. Borrowing from Graham Ward (2005), he argues that Arab Muslims must develop broader intersubjective practices and maximise their use of institutions as they strive for progress.

Meanwhile, in the context of intersubjective practice, Hasan Hanafi describes and analyses the renewal of Islamic jurisprudence, theology and philosophy. Beginning by tracing their development, Hasan Hanafi discusses the possibility of reconstructing these fields to better suit contemporary realities. To provide a theoretical foundation for such renewal and thereby promote a new, dynamic ideology, Hasan Hanafi wrote the book At-Turāts wat-Tajdìd. This was followed by AlYasār al-Islāmy (the Islamic Left), which is more of an ideological 'political manifesto' rather than a guideline for renewal. Only with Min al-Aqīiah ilā al-Tsaurah (five volumes), written over the course of 10 years and published in 1988, did Hasan Hanafi detail the key tenets and programmes of the Islamic renewal that he had promoted in his earlier works. As such, it is not surprising that Min al-Aqìdah ila alTsaurah is considered his most monumental work.

Central to this book is the need to reconceptualise theology, to enable the Arab people to understand theology not as static, but as dynamic and oriented towards liberation and social 
justice. Firstly, Hasan Hanafi attempts to delineate his entire work and theological orientation in terms of its genesis, content, methodology and development. He then attempts to analyse its strengths and weaknesses, particularly in terms of its relevance to modernity. He concludes that classical theology has remained highly theoretical, elitist and conceptionally static. He recommends a new theology, one that is anthropocentric, populist and transformative (Hanafi 1982:55).

Between 1985 and 1987, Hasan Hanafi wrote numerous articles that he presented at international seminars in the United States, France, the Netherlands, the Middle East, Japan and Indonesia. These articles were later collected in his book Religion, Ideology, and Development, which was published in 1993. Several of his other writings were collected in the two-volume Islam in the Modern World. In his most recent writings, Hasan Hanafi has conducted not only religious and philosophical explorations, but also social and technological ones. He has focussed more on religion and its position in the development of the Third World.

Over time, Hasan Hanafi has stopped focussing on specific ideologies, but rather on new paradigms that reflect the teachings of Islam congruent whilst simultaneously meeting the needs of contemporary Muslims. This sublimation of Hasan Hanafi's thought was driven in part by a shift in Egyptian politics, from the socialism of the Nasser government to the pragmatic nationalism of Anwar Sadat. He has been developing this new paradigm since the mid1980s (Hanafi 2016:19). His universalistic perspective has, on the one hand, sought to integrate Islamic discourse into the everyday lives of Muslims and affirmation of human dignity through the achievement of individual autonomy, legal sovereignty, recognition of human rights and empowerment of the common people. On the other hand, Hasan Hanafi's universalistic perspective represents a development of the epistemology of new science (Hanafi 2016:37).

In this context, Hasan Hanafi argues, Muslims cannot simply accept and expropriate Western paradigms that are rooted in materialism, but must also avoid eradicating Arab intellectual culture. A selective and constructive dialogue with Western civilisation is necessary to ensure an appropriate understanding of the Western world. In an academic context, it is necessary to apply an Occidentalist (al-Istighräb) approach to balance out Orientalism (al-Istisyrāq) (Hanafi 1991:38). Occidentalism, for Hasan Hanafi, is a means of understanding Western civilisation as it is; as such, it is something that can produce the understandings and policies needed for the long-term development of the Islamic world, including a dynamic new theology that entails liberation and social justice. Hasan Hanafi thus offers the possibility that Islam and the West can work side by side in creating a new and universal culture and civilisation.

\section{Hasan Hanafi's concept of cultural revolution}

Although Hasan Hanafi offers some criticism of the West, he still applies and focusses on pre-modern and modern
Western thought (Daifallah 2012:49). As Hasan Hanafi has been heavily influenced by such Western liberal ideals as democracy, rationalism and enlightenment, Shimogaki categorises him as a modernist liberal (Shimogaki 1988:68). According to Issa J. Boulatta in his book Trends and Issues in Contemporary Arabs Thought, Hasan Hanafi's thought has three foundations: (1) Islamic tradition and history, (2) phenomenology and (3) Marxian social analysis. As such, his 'leftist Islam' may be understood as a type of knowledge that socially constructed within a class society, reflecting the Marxian tradition (Boullata 1990:42-45).

Hasan Hanafi emphasises the need to reconceptualise classical theology, producing a new theology that does not imply the loss of old traditions. His new theology does not demand the eradication of historically maintained traditions. These traditions can still be maintained and even integrated into contemporary reality. In this new theology, dialectics must be made to manifest through action, rather than arguments between individuals. This, he argues, will enable Muslims to achieve worldly success and empower themselves through independence, liberty, unity, progress and mass mobilisation. His new theology is targeted towards humanity and as such must be formulated on a humanitarian basis (Hanafi 1983b:7).

The fundamental assumption of Hasan Hanafi's new theology is that Islam is protest, opposition and revolution. For Hanafi, Islam has a dual meaning. Firstly, Islam is a submission enforced by the political power of the upper class. Secondly, Islam is revolution, something made real by a powerless minority and the poor. As such, when maintaining the status quo, a political regime will interpret Islam as submission; meanwhile, where socio-political change is desired, Islam is interpreted as revolution (Hanafi 1983b:104). In this context, the term aslama is understood as surrendering oneself to Allah rather than any other. This indicates the duality of power, of the transcendental and the non-transcendental (Hanafi 1983a:104). The duality of the verb aslama and the noun Istām, Hasan Hanafi argues, is deliberately misappropriated to emphasise only one aspect of Islam: submission. As such, the reconceptualisation of traditional theology also means the recognition of another aspect of Islam: rejection, opposition and revolution, all of which Muslims need when dealing with regimes that do not provide liberty or social justice. As such, Islam is integrally linked with the manifestation of liberty and justice, whilst also reflecting the universal values that shape social structures and political power.

In his book Min al-Aqīdah ilā al-Tsaurah [From Creed to Revolution], Hasan Hanafi explains that he understands revolution not as a mass movement, coup d'état, or armed conflict, but rather a cultural revolution through which the Arab-Muslim people can mobilise their minds and re-actualise their ideology. Such a revolution focusses on transforming the understanding of tauhid from a passive creed - one that does not influence individual, social or 
historical life - into a progressive one. Quoting Muhammad Iqbal, an important Pakistani thinker and author, Hasan Hanafi writes that tauhid is a dynamic revolutionary force. Unfortunately, however, classical understandings of tauhid are static, focussing solely on understanding the essence, character and actions of Allah.

Hasan Hanafi explains that humanity's faith in Allah, in creation, in prophecy and in the afterlife has the potential to positively transform the mind and soul, imbuing humanity with a particular spirit and power (Hanafi 2001:44). Faith in Allah is truth, something that guides humanity towards tauhid, whilst philosophy and contemplation offers an instrument for attaining scientific truth. The goal of human existence is to attain an understanding of truth, which is made possible through philosophy (Stone 2006:60). The basis of Hasan Hanafi's cultural revolution is the assertion of tauhid: Lā Ilāha illa al-Lāh [There is no god save Allah]. The phrase La Ilāha [there is no god] is a denunciation of 'false gods' such as wealth, high office and power, whilst the phrase illa al-Lāh [except Allah] is an assertion that only Allah is the Almighty and the All-Uniting. This sentence is part of faith, of practice and imāmah [leadership] and offers a mental revolution that can inspire a physical revolution (Hanafi 1998:15), which can lead in turn to a cultural revolution that will address the regression and fragmentation of the Arab Muslim world.

Physical revolution, which is more political in nature, is allowed when those in power deliberately violate the principle of social justice and subjugate the powerless. In such a context, thinkers and scholars are limited to contributing their thoughts on cultural revolution. If their ideas inspire others to revolutionary action is not up to them; it will be determined by political actors. Hasan Hanafi makes this point by referencing the French Revolution, which was inspired by the thoughts of Voltaire, Rousseau and Montesquieu, as well as Iran's transformation from a secular to an Islamic republic, which was inspired by Islamic scholars but mobilised by Ayatollah Ruhollah Khomeini.

Hasan Hanafi disapproves of tasawuf (and its institutionalisation through tarekat [schools]) where passivity and surrender to mortality are underscored. Tarekat is a medium through which humans can satisfy their longing for the divine by following a charismatic religious scholar. As such, the revolution offered by tarekat is one of magicism and self-sacrifice $(a l-F i d \bar{a})$. Such a revolution, Hasan Hanafi argues, is not the one needed by the Arab people; rather, they require a revolution of consciousness, a revolution of thought and a revolution of textual interpretation (Hanafi 1998:15), all of which are ensconced in his concept of cultural revolution.

Hasan Hanafi's cultural revolution is a concept intended to empower the Arab people, as a social fact, and enable them to reclaim the glory of Islamic thought. In this context, a social fact is constructed through practice. Hasan Hanafi distinguishes between practice and concept, writing that, if practice is done publicly, it can be seen and heard; a concept or idea, meanwhile, cannot (Rawls 2004:7). By linking his concept of cultural revolution with social practice, he underscores the importance of revising the classical definition of tasawuf that understands life as a total surrender to Allah, as becoming one with Allah, similar to the Hindu concept of Nirvana. Hasan Hanafi understands tasawuf differently, as requiring humanity to have a baqā on earth; in other words, human beings must be brought back to earth, to co-exist with the poor and the destitute. Tasawuf is not simply a matter of sabar [patience], tawakal [trust in Allah], wara' [self-preservation], ridha [gratitude], khauf [fear], khasyyah [concern] and istisl my [passivity], but also an orientation towards opposing injustice, rejecting evil, thinking progressively and cultural revolution. Hanafi views Sufism as a convergence of metaphysics and ethics, which according to Meister Eckhart is shown in the concept of 'detachment' (Eckhart 2009:566-574). This concept describes human freedom from libidinous entanglement as well as human cognitive freedom, that is freedom from images of physical objects, which serve to limit the mind and isolate it from its own transcendental possibilities. As the metaphysical keyword of spiritual reality and divine reality is unity, the moral manifestation of this state is the practice of altruism, namely treating others as if they were themselves. Therefore, according to Eckhart, we must care concerning the welfare of others just as we care concerning ourselves (Eckhart 2009:569).

Amongst the most important themes in Hasan Hanafi's concept of cultural revolution is his understanding of reason ('aql). Hasan Hanafi does not understand reason by using its common definition, as the mental process through which one can gain an understanding of previously suspected knowledge (Hanafi 1989b:135). Similarly, Hasan Hanafi does not understand reason as rationalists do, seeing it as an activity through which people can obtain previously unknown knowledge (Hanafi 1989b:135). Logic is not simply the process of listing what is known or suspected to obtain further knowledge, as seen in syllogism (Hanafi 1989b:135). The first definition of reason, according to Hasan Hanafi, has a number of problems - particularly its idea of preconception. For Hasan Hanafi, a preconceived notion that proves untrue is foolishness, and foolishness is something to be avoided. Furthermore, this first definition fails to explore the essence of logic, looking instead at its elements (Hanafi 1989b:135). Meanwhile, the second and third definitions, Hasan Hanafi argues, are neither comprehensive nor suited to a free or correct logic (Hanafi 1989b:136). The main problem of deductive reasoning, according to Hanafi, is that it requires the human mind to be truly clear and focussed. To think logically, the human mind requires two premises, from which it can draw a conclusion. If the mind is not focussed, human 'logic' cannot produce any significant truth. 
Hasan Hanafi holds that reasoning is a process of observation, directed both internally and externally. The former is a process of protecting the soul from imprudence, whilst the latter is oriented towards one's goals (Hanafi 1989b:136). As such, for Hasan Hanafi, to 'reason' is to conduct academic research by combining both deductive and inductive reasoning. Intelligent research, he argues, does not only objectively observe something from the outside, but sometimes considers it subjectively and emotionally, even empathetically. As such, Hasan Hanafi understands reasoning as research, but this research is understood not through the positivistic lens of modern science but rather a naturalistic, constructivist and interpretative lens.

Transforming how 'reason' is understood, thus, is not only a central theme of Hanafi's cultural revolution, but also an important and strategic move for the Muslim world. Reason may not only be understood as logical-deductive, as a reliance on deductive reasoning has historically limited the initiative and creativity of the Muslim world. Reason must be understood as a convergence of deduction and induction, thereby enabling Muslims to maintain their intellectual heritage without ignoring modern innovations and empirical findings.

The cultural revolution that Hanafi aspires to have not immediately succeeded in changing the order and structure of Egyptian society. The cultural revolution that was promoted by Hanafi through his sharp criticism of classical theology by offering a new theology (the Islamic Left) did not directly succeed in transforming the Egyptian nation into a nation that was democratic, egalitarian, just and equal before the law. However, Hanafi's ideas became an inspiration for intellectuals, youths and Muslim activists not only in Egypt but also in various friends in other Muslim countries. The idea of the Hanafi cultural revolution has become a 'model' for intellectuals and young communities in building a civil society that fosters a spirit of partiality and advocacy for the poor, weak and marginalised. In Indonesia, for example, a country with the largest Muslim population, the thought of Hanafi, which was introduced for the first time amongst others by Abdurrahman Wahid and Yudian Wahyudi (Kersten 2019:43), has sparked the spirit of intellectuals to not only stay in ivory towers but also participate in fighting to promote the realisation of social justice, democracy and uphold human rights.

\section{Conclusion}

From the above discussion of Hasan Hanafi, new theology and cultural revolution, several conclusions may be drawn. The Arab world must find a solution to its major problems, promoting a revival of Islamic thought and revivifying Arab pride and passion. He identifies the long-term conflict in the Arab Muslim world as being caused by the friction between Islamic ideology, Western ideology and socialism. Classical theology has been unable to answer the challenges of modernity because, conceptually, it remains highly theoretical, elitist and static. He instead promotes a new theology, a grounded theology that is anthropocentric, populist and transformative, one capable of promoting welfare and social justice. This new theology does not need to erode Arab-Islamic traditions and culture; rather, it must guide Muslims towards independence, liberty, unity, progress and mass mobilisation.

Cultural revolution, meanwhile, offers a liberational ideology for the subjugated as well as legitimisation for every social struggle. It also holds that no entity that exists on its own, without any humanitarian context, has meaning; there is only a correlational truth connecting objective reality and universal human values. As such, new theology - in conjunction with cultural revolution - can radically transform the orientation of Arab-Islamic thought from static, passive and traditional to progressive and oppositional. In doing so, it can offer liberation and social justice.

\section{Acknowledgements}

The author would like to acknowledge Prof. Dr Syamsul Hadi, S.U., M.A.; Prof. Dr Sangidu, M.Hum.; Dr Amir Ma'ruf, M.Hum.; and Dr. Uswatun Hasanah, M.A. for comments that greatly improved the manuscript. He would also like to show his gratitude to Dr Mohamad Masrukhi, M.Hum.; Abdul Jawat Nur, S.S., M.Hum.; and Dr Hindun, M.Hum for sharing their pearls of wisdom with him during the course of this research.

\section{Competing interests}

The authors have declared that no competing interests exist.

\section{Author's contribution}

F.M.M. contributed to the entire research process, starting from the elaboration of ideas, the development of theories, data analysis, to the writing of the manuscript.

\section{Ethical considerations}

This article followed all ethical standards for a research without direct contact with human or animal subjects.

\section{Funding information}

This research received no specific grant from any funding agency in the public, commercial or not-for-profit sectors.

\section{Data availability}

Data sharing is not applicable to this article as no new data were created or analysed in this study.

\section{Disclaimer}

The views and opinions expressed in this article are those of the authors and do not necessarily reflect the official policy or position of any affiliated agency of the authors. 


\section{References}

Abdullah, M.A., 2006, Islamic studies di perguruan tinggi: Pendekatan integratifinterkonektif, Pustaka Pelajar, Yogyakarta.

Allosh, I., 2018, Rationality and resentment in the Egyptian critique of orientalism: The example of Anouar Abdel-Malek and Hasan Hanafi, The University of Arizona, Tucson-Arizona.

Beyers, J., 2017, 'Religion and culture: Revisiting a close relative', HTS Teologiese Studies/Theological Studies 73(1), 1-9. https://doi.org/10.4102/hts.

Boullata, I.J., 1990, Trends and issues in contemporary Arab thought, State University of New York Press, New York, NY.

Browers, M., 2004, 'Modern Islamic political thought', in G.F. Gaus \& C. Kukathas (eds.), Handbook of political theory, pp. 367-379, Sage, London.

Cox, J.L., 2006, A guide to the phenomenology of religion, key figures, formative influences and subsequent debates, T\&T Clark International, London.

Daifallah, Y.S., 2012, Political subjectivity in contemporary Arab thought: The political theory of Abdullah Laroui, Hassan Hanafi, and Mohamed Abed Al-Jabiri, University of California, Berkeley, CA.

Davies, D., 2016, 'Cultural intensification: A theory for religion', in D.J. Davies \& M.J. Thate (eds.), Religion and the individual: Belief, practice, identity, Routledge, London.

Day, A., 2016, Religion and the individual: Belief, practice, identity, Routledge, London.

Eckhart, M., 2009, The complete mystical works of Meister Eckhart, in M.O. Walshe (ed.), pp. 479-588, The Crossroad Publishing Company, New York, NY.

Esposito, J.L. \& John, V., 2001, Makers of contemporary Islam, Oxford University Press, Oxford.

Hanafi, H., 1977a, Contemporary issues, Anglo-Egyptian Bookshop, Cairo.

Hanafi, H., 1977b, Religious dialogue and revolution, Anglo-Egyptian Bookshop, Cairo.

Hanafi, H., 1977c, Tradition and modernism, Arab Center for Research and Publication, Cairo.

Hanafi, H., 1982, 'The relevance of the Islamic alternative in Egypt', Arab Studies Quarterly 4, 54-74.

Hanafi, H., 1983a, Qadhāyā Mu āshirat Fi`Fikrina Al-Mu`āshir, Dārut-Tanwīr lithThibā'atin-Nasyr, Beirut.

Hanafi, H., 1983b, Qadhâyâ Mu’âshirat Fi'Fikrinal-Mu'âshir, Dârut-Tanwîr lithThibâ'atin-Nasyr, Beirut.
Hanafi, H., 1987a, Ad-Dîn Wat-Tsaurah Fi Mishr, 1952-1981, A1-Maktabatu1Madbûly, Cairo.

Hanafi, H., 1987b, Al-Dīn Wa Al-Tsaurah Fi Mishr 1952-1981, Al-Maktabatu alMadbūly, Cairo.

Hanafi, H., 1989a, From Dogma to revolution, Al-Maktabatu al-Madbūly, Cairo.

Hanafi, H., 1989b, Min Al-'Aqīdah Ilā Al-Thawrah: Al-Muqaddimāt Al-Nazariyyah, AlMaktabatu al-Madbūly, Cairo.

Hanafi, H., 1989c, Theosophy and phenomenology: Islamic studies, Anglo-Egyptian Bookshop, Cairo.

Hanafi, H., 1991, East-West dialogue (with Al-Jabiri), Al-Maktabatu al-Madbūly, Cairo.

Hanafi, H., 1998, Generations dialogue, Dar Keba, Cairo.

Hanafi, H., 2001, From transfer to creativity, Dar Keba, Cairo.

Hanafi, H., 2012, 'From Orientalism to Occidentalism', Encounters in Language and Literatur 1(2), 7-16.

Hanafi, H., 2016, 'As-Salafiyyāt Wa Al-'Ilmāniyyāt Fi Fikrina Al-Mu'āshir', Al-Azminat 3(15), 15-47

Kersten, C., 2019, Contemporary thought in the Muslim world: Trends, themes, and issues, Routledge, London.

Mantzavinos, C., 2005, Naturalistic hermeneutics, Cambridge University Press, Cambridge.

Phillips, D.Z., 2003, Religion and the hermeneutics of contemplation, Cambridge University Press, Cambridge.

Poster, M., 2019, Critical theory and poststructuralism: In search of a context, Cornell University Press, Ithaca, NY.

Rawls, A.W., 2004, Epistemology and practice: Durkheim's the elementary forms of religious life, Cambridge University Press, Cambridge.

Roy, O., 1996, The failure of political islam, Harvard University Press, Harvard.

Said, A.A., Abu-Nimer, M. \& Sharify-Funk, M., 2006, Contemporary Islam dynamic, not static, Routledge, London.

Shimogaki, K., 1988, Between modernity and post modernity: The Islamic left and Dr. Hasan Hanafi's thought, Institute of Middle Eastern Studies, International University of Japan, Tokyo.

Stone, G.B., 2006, Dante's pluralism and the Islamic philosophy of religion, Palgrave Macmillan, New York, NY.

Sutcliffe, S. \& Bowman, M., 2000, Beyond new age: Exploring alternative spirituality, Edinburgh University Press, Edinburgh.

Ward, G., 2005, Cultural transformation and religious practice, Cambridge University Press, Cambridge. 